\title{
How Culture, Gender, Religion, Social Class, and Voyeurism Together Shape Individuals' Eating Behaviors: A Discourse on Food Communication
}

\section{Gulcin Ipek Emeksiz}

Anadolu University, Communication Sciences Faculty, Department of Communication Design and Management, Eskisehir, Turkey

Email: giemeksiz@anadolu.edu.tr

How to cite this paper: Emeksiz, G. I. (2021). How Culture, Gender, Religion, Social Class, and Voyeurism Together Shape Individuals' Eating Behaviors: A Discourse on Food Communication. Advances in Journalism and Communication, 9, 63-73. https://doi.org/10.4236/ajc.2021.92005

Received: March 11, 2021

Accepted: May 11, 2021

Published: May 14, 2021

Copyright $\odot 2021$ by author(s) and Scientific Research Publishing Inc. This work is licensed under the Creative Commons Attribution International License (CC BY 4.0)

http://creativecommons.org/licenses/by/4.0/

\begin{abstract}
Food is a way of communication that many of us aren't often aware of because most of us think that we only consume food to satisfy our temporary hunger. However, food can, in fact, be approached from a semiotic perspective because it includes many signs such as culture, gender, religion, class, and voyeurism within. Therefore, food should be examined from a semiotic perspective just as Roland Barthes has said. Barthes claims that how the food appears on a plate, with which methods it has been prepared, how it is served, the way it is eaten with table manners, the senses that it creates all convey some meanings because they are all a combination of different sign systems which help people to communicate (Faber \& Claramonte, 2017). Therefore, in this research paper, how consuming a type of food can actually shape an individual's identity and how the discourse on food from many different angles, which are culture, gender, religion, class, and voyeurism, can be formed are discussed. (Fiske, 2003) mentions that people sharing the same codes and using the same semiotics systems will be able to look from the same perspective and will perceive signs in a similar way, so this is about the frame of reference that we use in communication because the reader uses her/his own experiences and emotions while giving a meaning.
\end{abstract}

\section{Keywords}

Culture, Gender, Religion, Class, Voyeurism, Consumer Society, Globalization, Food, and Communication 


\section{Introduction}

While maintaining their lives, human beings need to consume food, which is basically found in the nutrition chain formed out of carbohydrates, protein, and fats, and there are mainly three reasons why people consume food which are biological reasons to survive, to get nutrition and pleasure from what we eat, and to cope with boredom or loneliness (Avena, 2015). Food is an important part of many people's lives in the world. As human beings burn calories and do activities during the day, they need to consume some amount of food, and this depends on their gender, and thus consuming food is a basic need and with our instincts, we crave some food during our meals. However, what makes us different from other living beings such as animals is that while we consume food, we also form social relationships. In other words, human beings don't just consume food to full themselves; instead eating food is about socializing, and thus food isn't just a biological or a nutritional need, but it is also required for the maintenance of social relationships (Gunter, 2016).

While we engage in conversations at the table with our companions, we talk about the things that we feel important that day such as things, which have made us happy, angry, or sad. Sometimes, we tell funny stories that have happened to us in the past in order to cherish the atmosphere. Sometimes, we take important decisions or we talk about our plans. Meanwhile, we behave according to table manners and most importantly we talk according to the background of the person that we talk to.

Also, the discussions that we bring to the table are not always restricted to formal things. For instance, the social meetings such as female friends' gatherings named as "gün" or "my day" in the Turkish culture that each individual in the group picks a date and prepares for it either serving usually high-calorie tasty food to their friends in their houses or treating a meal to their friends at a restaurant brings along nice chatting and the latest gossip at the weekends. Also, in Turkish culture, drinking tea in a fine waisted teacup or drinking Turkish coffee in small coffee cups brings along pleasant conversations when a friend orders one because it is a cultural thing.

\section{The Purpose and Method of the Research}

As human beings, we define who we are with the food that we consume and we create our identities. As a technique semiotics helps the researcher to analyze a sign representing something else and the viewer should interpret the signs within the cultural context that they are found in and should disclose the concealed meanings (Daymon \& Holloway, 2011). For instance, in Westernized cultures, individuals create their identities with the food that they consume, food is a way of establishing their identity because they signify not only their femininity or masculinity but also their social class with it (Germov \& Williams, 2017). According to Bourdieu (1989) how people select which foods to consume is a way of showing their distinction from other people in society, and thus food doesn't 
have any difference from fashion in terms of showing social class (Hartog et al., 2006). In other words, food is an element, which helps us to define our social class and helps us to belong to a specific group such as a gender group. For instance, while eating high-class meals in an elite restaurant separates one person from the lower classes, eating vegan food might also be a preference of femininity, as well. As one of them signifies class, the other one signifies gender.

Therefore, the aim of this research paper is to discuss how the culture, gender, religion, and social class that one belongs to, in fact, shapes her or his identity of consuming food by also mentioning the globalization dimension of everyday reality. With this purpose, this paper scrutinizes five topics, which are culture, gender, religion, social class, and voyeurism. It aims to show these elements' place in an individual's life in today's consumer society by focusing on the topic of food communication, and it aims to put a literature review forward. A literature review helps the researcher to demonstrate the main points that she has read from diverse resources by putting her own interpretation and by coming with a fresh perspective, and this way she makes a contribution to the previous knowledge with her new ideas (Creswell, 2002). Semiotics can be defined as a system of signs with which people agree upon since it carries a logic within (Chandler, 2007). A sign is composed of three elements, first of all, what it is actually, then the code system that it is found in and lastly how it is represented in a specific culture (Fiske, 2003). A sign always refers to and represents something different than itself (Özdemir, 2012). Also, how people will understand it the same way depends on the frame of reference that they have within their minds.

\section{How Class Shapes Our Eating Habits}

Social class is the group that one belongs according to the financial resources that one owns thanks to the jobs that she or he works and thanks to the heritage that she or he brings from her or his families and this can vary such as high-end, upper-middle class, middle class or working-class people. In terms of food, our choices of restaurants; in other words, the places that we prefer to dine contributes to shaping our self-identities while our social environments also have an effect on where we go and dine (Sloan, 2004). For instance, eating a minimalistic designed food such as a fusion in a stylish Michelin restaurant along with a glass of wine can be a sign of high-end class compared to eating a hamburger along with French fries and a bottle of coke at a fast-food restaurant which signifies a middle-class eating habit in many different cultures (Germov \& Williams, 2017).

In terms of class, the culture that one lives in determines her or his table manners, and it indicates the social class that one belongs. For instance, Westernized people use the spoon, fork, and knife, instead of eating with their fingers and they use a napkin instead of licking their fingers compared to the Arabic cultures (Conroy, 2014). Also, using table manners properly is a sign of belonging to high-end classes in certain societies. For instance, during the 1950s, 
Americans from the Upper East Side in New York can understand whether someone belonged to that high-social class or not from the way which fork they used in a meal, in other words, this gave them a clue about who was an outsider or not (Coggins, 2018).

However, there are some exceptions to these table manners for instance in fast food cultures of Westernized societies which are a part of the consumer society, people eat with their hands, as well, and the way that the fast-food restaurants are designed is always with seats that makes one uncomfortable after sitting there some time because they are designed for circulation of many people, one should eat fast and then leave the restaurant without consuming so much time there so that another person can come and sit (Conroy, 2014). So, using a fork or using hands while eating a meal are different signs, which give completely different meanings. For the latter, this is explained with the process of standardization named "McDonaldization" because each fast food restaurant is designed the same way and they are opened in many numbers in different locations in the world with the same concept and the same kind of food (Germov \& Williams, 2017).

Nevertheless, in order to adapt to the local conditions of specific cultures where they open branches, McDonald's once created local menus and this process is explained as glocalization, which refers to the melting point of the global and local tastes. One thing, which results from glocalization, can be seen in the different classes or the target audience that fast-food restaurants attract in different countries. In other words, the social classes that fast-food brands draw to their restaurants can have some differences depending on the country where they are opened. While fast-food restaurants mainly appeal to the lower classes in the U.S.A, it appeals to the white-collar people in other countries such as Turkey and China because people consume fast food as a part of showing that they are attaching to the American lifestyle and they relate the style of fast-food restaurants to modernism and it is seen as a part of experiencing the American culture (Gunkel, 2016).

For instance, when Mc Donald's became so popular in Turkey for the first time, the parents of young kids celebrated their children's birthday parties at Mc Donald's by inviting their friends from their classes at primary school and it was a way of doing something fashionable and the toys that Mc Donald's gave along with the kid's menu and the clown entertaining the kids by painting their faces led many children to have a wish to celebrate their birthdays at Mc Donald's. Therefore, the meaning of fast food changes outside the U.S.A in different cultures. However, this trend has been also changed in time in Turkey, and celebrating birthdays at McDonald's has been abandoned and fast food has become something ordinary and easily reachable for many common people living in Turkey.

Coffee shops like Starbucks are recent examples of the McDonalization process. Starbucks has also added Turkish coffee to its menu in order to adapt to the glo- 
calization process. Besides, Starbucks is another example of the term "culture industry" that the Frankfurt School thinker Adorno put forward because it provides an entertaining choice for people to spend their leisure time, and it also relieves the person who goes there because she or he forgets about her or his daily responsibilities when she or he spends a good time there (Dağtaş \& Dağtaş, 2019).

Starbucks offers many choices varying in taste and size to people who want to express some elements about their personality. For instance, the coffee choices of people tell something about their preferences as a gender group. A frappuccino, a white chocolate mocha, a chai tea latte or a caramel latte signify femininity while an espresso, a filter coffee, an Americano or a cold brew latte signifies masculinity. Moreover, teenagers living in urban cities usually choose Starbucks coffees as the meeting place because coffee signifies conversation. In addition, the modern architecture of the coffee shop gives them the right amount of time to chat due to the circulation of many people. These teenagers prefer Starbucks coffees not only as a way to spend their leisure time by socializing with their friends, but they also do some assignments thanks to the free wi-fi service at the coffee shop. In Turkey, students who go to universities usually prefer Starbucks as the meeting point to do a group project with their laptops while sipping their coffees.

Also, some teenagers use Starbucks as a symbol of the "culture industry" at the weekends before going to movies with friends, and they imply that they are living a modern lifestyle. For many students in Turkey, the price of a Starbucks coffee, which is higher than the average coffee sold at the supermarkets, helps them to show their friends that they are actually consuming a hip brand image. In addition, some people grab their coffees while going to work, and this way they show that they are busy, and they are white-collar people.

Furthermore, the supermarkets that one shops from and the brands that one prefers to buy also tell something about the class one belongs to. The supermarkets located in the fashionable districts of the city versus the ones located in the suburbs or the brand of a product whose price is more expensive than the other are all considered a way of communication for the social identity of the individual according to where she or he shops and buys.

The supermarkets contain various food choices. Food advertisements help make some brands more noticeable and more demanding by promoting certain brands for a specific group of people related with their class, and while these advertisements try to persuade people to prefer these brands because of their brand image, they have an effect on their diets, as well (Gunter, 2016). The brand image is a sign, which displays the prestige given to the individual thanks to her or his affordance of the particular product and which helps to increase her or his social status because of consuming it. However, in order for other people to understand and recognize the prestige that the product brings along, everybody needs to interpret the signs from the same perspective and they are actually 
supported through the messages given in advertisements (Palma et al., 2017).

Food advertisements mainly influence the purchase intentions of consumers while they also affect what kind of purchase behavior these consumers will develop later on (Flynn et al., 2020). In today's world, food advertisements aren't just related with people's nutrition habits, instead they are more associated with the brand image of the product, the social status and self-esteem that it brings along, and these advertisements especially target special groups with specific consumer behaviors (Gunter, 2016). Therefore, some individuals mainly do conspicuous consumption of food to distinguish themselves from lower classes and these individuals are looking for prestige with their motivation to pay more for certain food brands (Palma et al., 2017). Moreover, the meals that one prefers to cook daily, the ingredients that one prefers to use, the drinks that accompany one's meals, they are all hints about the social class that one belongs to because they tell something about the budget that one shares for nutrition. Thus, the class group that a person lives in has an influence on which food products she or he can reach, and cook in their meals. Briefly, food is a concept, which should be thought together with class in various ways given with the examples of high-end meals, consumer culture, culture industry, globalization, modernism, and conspicuous consumption.

\section{How Culture Shapes Individuals' Eating Habits}

Westernized cultures mainly categorize food such as good and bad, and while good food consists of elements such as nutrition, health, pureness, cleanness, lightness, and refinement, bad food contains elements such as illness, disease, pollution, artificialness, fatness, and hedonism within (Lupton, 1996). This is mostly related to the fact that eating isn't about just getting pleasure from the act of eating or taking energy from the food that we consume any more, it is named as a political act because people are more aware of the pros and cons of the food industry that we are living in this century (Woolf, 2014). For instance, there were many debates about whether corn, corn feed and chicken contained genetically modified organisms for a long time on news in Turkey and people were soothed down with the precautions taken.

Furthermore, individuals' eating habits are actually shaped by the cultures that they are living in and it is the specific culture, which determines and classifies different food as edible or not (Germov \& Williams, 2017). In other words, the things which shape our eating behaviors consist of a couple of things such as the region of the world that we are living in, the religious group that we belong to, the class that we come from, the gender that we are born, and the eating habits of our families (Seymour, 2004).

For instance in Turkey nowadays, the parents, who are more conscious, don't want their children to eat junk food such as chips that are greasy, or they don't want their children to drink soft drinks with too much sugar in them so that their children can have a healthy development and don't become obese. 


\section{How Religion Affects People's Eating Habits}

Also, it is common for family members to eat healthy home-cooked dinner meals together, and have Sunday breakfasts together; while family members eat lunch during the day separately according to their own schedules outside. Moreover, ingredients containing pork aren't used in home-cooked meals because the majority of people living in Turkey are Muslim people and eating pork is forbidden in the Muslim religion, as it is not seen as healthy. Thus, the way people consume meat is different than how other people consume it in other Western countries because Turkish people use halal food products since it is a cultural thing.

The way the manufacturing process of meat is done is based on faith-based rules because Turkish people believe that this way the meat is prepared more healthfully and it tastes more delicious since the faith-based rules bring hygiene conditions along and most people living in Turkey want to consume meat halal way and for many liberal and open-minded people living in Turkey this has nothing to do with the religious compulsion, instead they prefer it mainly because they believe that this way of consuming meat is more healthy (Wilkins et al., 2019).

\section{The Role of Gender on Food Choices}

Consuming meat is considered consuming a masculine food because it represents hunting, being aggressive, and being dominant since meat has animal muscles and blood within it, and thus while men eat meat in larger amounts, women abstain from eating too much meat instead they eat meat in moderate amounts because this is a way of showing their femininity (Germov \& Williams, 2017). Moreover, during their lifespan women eat more vegetables and fruits containing fibers than men, they also tend to eat more home-cooked meals that are healthy whereas men incline to eat their meals outside more (Lombardo et al., 2020). Men are associated with food that has high levels of fat and calories such as a hamburger, whereas women are associated with low-fat foods that help them to preserve their ideal body forms (Cavazza et al., 2020).

Thus, another way of categorizing food as masculine or feminine is that feminine food consists of diet products based on losing weight such as cereals, yogurts helping to digestion, skim milk, salad, and herbal tea whereas masculine food includes energy drinks such as a Burn or a Red Bull and protein bars. For instance, the advertisements of Burn, a popular energy drink in Turkey, usually put feminine sexuality forward in order to attract men, whereas Red Bull, a well-known global energy drink, shows the power of men while accomplishing different things, and protein bars are usually shown as a part of the companion of masculine exercise such as climbing a mountain.

Also, there are times when people want to consume some food just for enjoying it because they like the taste so much and chocolate belongs to this category. Chocolate is a food, which is delicious and it gives one pleasure when she or he 
eats it, and thus one starts eating it she or he cannot give it up easily. For instance, women usually have cravings for chocolate and sometimes they may be addicted to it, and this can be explained as an intense desire; however, it's too much consumption inevitably leads to excess gain of weight (Mason \& Epel, 2015). Chocolate gives an intense desire because it is associated with an aphrodisiac effect and it is commonly used in romantic atmospheres such as Valentine's Day celebration at chic restaurants as it gives a sensual pleasure to the taster (Afoakwa, 2016). For instance, strawberry sticks, which are dipped into chocolate sauce, are presented together with a glass of champagne before the start of dinner at Valentine's Day celebrations. Thus, chocolate signifies romance in this context.

Women tend to crave for chocolate more when they are bored, tired or in depression, whereas men crave for chocolate when they are happy and in a relaxed mood (Mason \& Epel, 2015). When women are in a diet, they think about food, which taste good such as chocolate, ice cream, pastry and cake, and dieting is also a boring activity, which makes most women depressed through the process. Eating chocolate is a part of hedonic eating because many women want to eat for mainly taking pleasure out of it, and it gives women a pleasant feeling and this happens by rewarding the functions of the brain because then their moods are elevated (Avena, 2015). Especially, chocolate influences the hypothalamus function of the brain, which creates sensual feelings in the eater (Afoakwa, 2016). The ratios that people crave for chocolate change according to gender and while $91 \%$ of women crave for chocolate, $59 \%$ of men crave for it (Mason \& Epel, 2015).

Even though, we mainly like to eat for mainly hedonic reasons; however, sometimes there are different circumstances such as the food that gives us pleasure while eating it sometimes don't give us the same feeling for instance when we are ill as we cannot taste very well, or the food that we normally find unappealing might become appealing for us all of a sudden when we are hungry, or the signs that we find on low-fat products' packages might lead us to buy them as we find them healthy (Avena, 2015). Especially, after the emergence of Covid-19, many people complained about the fact that they can't taste very well and that is considered a symptom of the illness. Thus, our eating habits don't always have hedonic bases all the time.

\section{How Aesthetics and Voyeurism Are Significant Parts of the Food Culture}

Furthermore, aesthetics is an important part of the culinary culture, and other than being tasty and each meal which is decorated in a plate can be named as a piece of art and it is presented for hedonic pleasure (Arikan \& Ekincek, 2016). Food images, which are created aesthetically, and which are presented to the gaze of the viewer become popular thanks to women's magazines, food blogs, and social networking sites such as Instagram and Pinterest (McDonnell, 2015). 
For instance, many monthly or weekly magazines, which are also a part of the consumer culture, use aesthetic food images and prepare culinary pages in order to attract more readers and this shows that another reason for people to eat food is to enjoy the meal that they eat. Moreover, most of the people who display their plates on Instagram do that for the reason of impression management and they put their plates for the stare of other people and this is a way of visual consumption (Cavazza et al., 2020). Also, the way that the modern chefs prepare food programs on television which they invite guests and which they display their modern food plates, has an effect on food voyeurism, as well.

For food voyeurism, the meal which is put on the plate should carry such elements as balance, taste, texture, color, shape, the portion, and aesthetic decoration, and also green vegetables are usually used in order to create a contrast or a harmony on the plate; therefore, they are frequently used as a visual, as well (Arıkan \& Ekincek, 2016). Food voyeurism is about creating a desire for an object, which is positioned as unreachable at the moment, but at the same time, it can be consumed through the gaze of the eyes and visualizing it in the mind at that particular moment (McDonnell 2015). In order to satisfy this emotion of hedonic thinking, people will tend to look at the food pictures in magazines or they will look at the pictures on food blogs instead of eating something to satisfy their temporary hunger.

\section{Conclusion}

A person's daily habits of eating food aren't just formed out of biological needs; it is indeed formed as a combination of many factors such as culture, gender, religion, social class, and voyeurism, and it is also a form of symbolic consumption as Barthes mentioned. This research paper showed from a semiotic perspective that in today's consumer society our social classes, our genders, the religious groups that we belong to, and the cultures that we live in, the places we shop from, the meanings we exchange with the symbols of products all have a tremendous influence on the food that we consume. Meanwhile, the taste, the odor, and the aesthetics of the food on our plates have an influence on whether we will like it or not, as well.

This paper indicates from a semiotic perspective that signs such as a fusion plate, wine, a fork, a napkin, vegan food, eating with hands, meat, hamburger, coke, coffee, the brand image on food products, energy drinks, a protein bar, skim milk, diet products, green vegetables, and chocolate all signify different meanings which are expressed throughout the paper.

Another important thing is that as human beings we also eat in order to create good social relationships and while doing that we pay attention to table manners. Before Covid-19, on special days, people used to organize formal meals or cocktails, romantic dinners, or sincere parties along with tasty food so that they can celebrate an event or have a good time with their friends, partners or acquaintances. Still, food is a great companion for social relationships. In conclu- 
sion, food has major importance in our lives because it has a role in shaping our social identities.

\section{Conflicts of Interest}

The author declares no conflicts of interest regarding the publication of this paper.

\section{References}

Afoakwa, E. O. (2016). Chocolate Science and Technology. Hoboken, NJ: John Wiley \& Sons. https://doi.org/10.1002/9781118913758

Arıkan, A. D., \& Ekincek, S. (2016). Yemeklerin Görsel Sunumu. In H. Yılmaz (Ed.), Bir İletişim Biçimi olarak Gastronomi (pp. 19-42). Ankara: Detay Yayıncılık.

Avena, N. (2015). Introduction. In N. M. Avena (Ed.), Hedonic Eating: How the Pleasure of Food Affects Our Brains and Behavior (pp. 1-7). New York: Oxford University Press. https://doi.org/10.1093/med/9780199330454.001.0001

Cavazza, N., Graziani, A. R., \& Guidetti, M. (2020). Impression Formation via \#foodporn: Effects of Posting Gender Stereotyped Food Pictures on Instagram Profiles. Appetite, 147, 1-7. https://doi.org/10.1016/j.appet.2019.104565

Chandler, D. (2007). Semiotics. London: Routledge. https://doi.org/10.4324/9780203014936

Coggins, D. (2018). Men and Manners: Essays, Advice and Considerations. New York: Abrams Image.

Conroy, T. M. (2014). Food and Everyday Life. Lanham, MD: Lexington Books.

Creswell, J. W. (2002). Educational Research. Planning, Conducting, and Evaluating Quantitative and Qualitative Research. London: Pearson Education.

Dağtaş, B., \& Dağtaş, E. (2019). Tüketim Kültürü, Yaşam Tarzları, Boş Zamanlar, ve Medya Üzerine Bir Literatür Taraması. In B. Dağtaş, \& E. Dağtaş (Eds.), Medya, Tüketim Kültürü ve Yaşam Tarzları (pp. 27-75). Ankara: Ütopya Yayınevi.

Daymon, C., \& Holloway, I. (2011). Qualitative Research Methods in Public Relations and Marketing Communications. Oxon: Routledge. https://doi.org/10.4324/9780203846544

Faber, P., \& Claramonte, M. C. A. V. (2017). Food Terminology as a System of Cultural Communication. Terminology, 23, 155-179. https://doi.org/10.1075/term.23.1.07fab

Fiske, J. (2003). İletișim Çalıșmalarına Giriș (Translation: Süleyman İrvan). Ankara: Bilim ve Sanat.

Flynn, M. A., Surprenant, T., Craig, C. M., \& Bergstrom, A. (2020). Is This Good for Me? A Content Analysis of the Healthiness of Food Advertised in Magazines. Atlantic Journal of Communication. https://doi.org/10.1080/15456870.2020.1821028

Germov, J., \& Williams, L. (2017). A Sociology of Food and Nutrition. The Social Appetite. South Melbourne, VA: Oxford University Press.

Gunkel, A. H. (2016). Food and Culture. In G. Burns (Ed.), A Companion to Popular Culture (pp. 243-264). Hoboken, NJ: John and Wiley Sons.

https://doi.org/10.1002/9781118883341.ch14

Gunter, B. (2016). Food Advertising. Nature, Impact and Regulation. Cham: Springer International Publishing. https://doi.org/10.1007/978-3-319-40706-7

Hartog, A. P., Staveren, W. A., \& Brouwer, I. D. (2006). Food Habits and Consumption in Developing Countries. Wageningen: Wageningen Academic Publishers. 
https://doi.org/10.3920/978-90-8686-667-0

Lombardo, M., Aulisa, G., Padua, E., Annino, G., Iellamo, F., Pratesi, A., Caprio, M., \& Bellia, A. (2020). Gender Differences in Taste and Food Habits. Nutrition and Food Science, 50, 229-239. https://doi.org/10.1108/NFS-04-2019-0132

Lupton, D. (1996). Food, the Body and Self. London: Sage Publications.

Mason, A., \& Epel, E. (2015). Craving Chocolate? A Review of Individual Differences, Triggers and Assessment of Food Cravings. In N. M. Avena (Ed.), Hedonic Eating How the Pleasure of Food Affects Our Brains and Behavior (pp. 57-83). Oxford: Oxford University Press. https://doi.org/10.1093/med/9780199330454.003.0004

McDonnell, E. M. (2015). Food Porn: The Conspicuous Consumption of Food in the Age of Digital Reproduction. In P. Bradley (Ed.), Food, Media and Contemporary Culture (pp. 239-265). Hampshire: Palgrave Macmillan. https://doi.org/10.1057/9781137463234_14

Özdemir, A. (2012). Popüler Kültür Tüketim Psikolojisi ve İmaj Yönetimi. İstanbul: Beta.

Palma, M. A., Ness, M. L., \& Anderson, D. P. (2017). Fashionable Food: A Latent Class Analysis of Social Status in Food Purchases. Applied Economics, 49, 238-250. https://doi.org/10.1080/00036846.2016.1194965

Seymour, D. (2004). The Social Construction of Taste. In D. Sloan (Ed.), Culinary Taste (pp. 1-22). Oxford: Butterworth-Heinemann. https://doi.org/10.1016/B978-0-7506-5767-9.50006-3

Sloan, D. (2004). The Postmodern Palate: Dining Out in the Individualized Era. In D. Sloan (Ed.), Culinary Taste (pp. 23-42). Oxford: Elsevier Butterworth-Heinemann. https://doi.org/10.1016/B978-0-7506-5767-9.50007-5

Wilkins, S., Butt, M. M., Shams, F., \& Perez, A. (2019). The Acceptance of Halal Food in Non-Muslim Countries. Effects of Religious Identity, National Identification, Consumer Ethnocentrism and Consumer Cosmopolitanism. Journal of Islamic Marketing, 10, 1308-1331. https://doi.org/10.1108/JIMA-11-2017-0132

Woolf, E. (2014). The Ministry of Diets. In E. Woolf (Ed.), The Ministry of Thin: How the Pursuit of Perfection Got out of Control (pp. 57-71). Berkeley, CA: Soft Skull Press. 